\title{
Public Debt and Economic Growth: A Scissor Effect in Developing Countries? The Case of Gabon
}

\author{
Médard Mengue Bidzo \\ Omar Bongo University, Libreville, Gabon \\ Email: menguebidzo@yahoo.fr
}

How to cite this paper: Bidzo, M.M. (2018) Public Debt and Economic Growth: A Scissor Effect in Developing Countries? The Case of Gabon. Modern Economy, 9, 1672-1686.

https://doi.org/10.4236/me.2018.910106

Received: July 20, 2018

Accepted: October 23, 2018

Published: October 26, 2018

Copyright $\odot 2018$ by author and Scientific Research Publishing Inc. This work is licensed under the Creative Commons Attribution International License (CC BY 4.0).

http://creativecommons.org/licenses/by/4.0/

\begin{abstract}
The multiple attempts at empirical evidence, yet recent, fail to truly dispel the theoretical vagueness of the effects of public debt on economic growth. The aim of this work is to demonstrate that public overindebtedness negatively impacts economic activity in developing countries. From estimation by the generalized moments' method in the system of the relationship between economic growth and outstanding public debt on data of the Gabonese economy, we get that an increase in the public debt in this country, causes a deceleration of economic activity, thus reflecting a scissor effect between public debt trend and that of economic growth.
\end{abstract}

\section{Keywords}

Public Debt, Economic Growth, Gabon, GMM

\section{Introduction}

Unconventional economic policies used to curb economic and financial crises seem to favour the public overindebtedness of economies [1]. The consequences of such behaviour on economic activity exacerbate discussions about the role of public debt. In this light, the use of excessive public debt poses a problem of economic efficiency in relation to the heavy consecutive tax burden and uncertainty about future tax conditions and the extent of public services that will be available in the future.

The analyses built around the impact of the public debt on economic growth followed two broad guidelines.

On one side, the one that reaffirms with new Keynesian arguments, that the public debt is an additional means for households to smooth their consumption 
[2] [3], on the one hand, and to reduce the costs of macroeconomic fluctuations that exacerbate the idiosyncratic risk of non-insurable income, thereby altering the need and cost of precautionary savings [4], on the other hand.

On another side, the one that argues that the incidence of public borrowing is generally neutral [5] and, at worst, that its introduction is not desirable because of the eviction of the physical capital it induces [6].

The first orientation is given by the Keynesian who praise the positive effect of an increase in public debt on growth, arguing that a budget deficit is an economic stimulus and therefore a job creation factor. The deficit to which the loan is applied stimulates demand and reduces the cost of reimbursement. Moreover, even in the event of a sub-activity, an increase in expenditure entirely financed by taxes leads to an equivalent increase in GDP, as tax burdens no longer hinder demand. Thus, the correlation between public debt and growth is clearly positive [7].

Mostly in the context of dynamic models of general equilibrium, these analyses neglect the relationship that could exist between the accumulation of the public debt and the policy mix within a monetary union, because the organization that Structure such a grouping may favour excessively lax, isolated budgetary policies. A clandestine passenger behaviour at the Olson [8], which would remain within such groupings of countries, coupled with macroeconomic fluctuations, would justify an exacerbation of the level of public debt.

The many attempts to demonstrate empirical evidence, however recent, fail to effectively dispel the theoretical vagueness of the debt effects on growth. The dominant vehicle design that the public deficit can stimulate short-term growth, but appears harmful in the long term [9].

In some circumstances, a negative effect on growth may occur, even in the short term.

First, high levels of public debt can cause markets to worry about the sustainability of the public debt or the slightest leeway for the counter-cyclical budget policy. Such concerns may result in an increase in the sovereign risk premium, that is, an increase in interest rates on the public debt, a swelling of the burden of public debt and perhaps ultimately a tightening of credit conditions For households and businesses. As well as Grauwe [10] pointed out, such effects may be more important for countries belonging to a monetary union, since they issue a debt in a currency on which they have no control.

Secondly, a country with a high level of public debt may be tempted to use inflation to erode the real value of debt held by creditors (monetization of debt), which in turn may lead the officers to raise their expectations Inflation [11].

In the end, the government of a country with a large debt is more inclined to use taxes to increase the necessary revenue and thus provide the service of its debt.

The second orientation is brought about by neo-classical reasoning, which focuses particularly on the eviction of productive investments and Ricardian equivalence. Debt is thus equated with future tax [5] [12]. 
At the same time, the relationship between public debt and growth raises the problem of overindebtedness.

Indeed, the theory of Overindebtedness considers that a high debt has a disincentive effect on the debtor country which is unable to undertake reforms conducive to economic growth or investment [13] [14]. This theory opposes the so-called "exogenous" relief decision to "endogenous".

As a result, the analysis demonstrating an exogenous relief decided by creditors may, in certain circumstances, increase the debtor's incentives to undertake reforms and avoid recourse to reimbursement [15].

However, the idea of endogenous relief demonstrates that by increasing the incentive of an overindebted country to undertake economic reforms, creditors can see the value of their receivables in the secondary market improve, as the prospects Repayment of the debtor increase [16] [17] [18].

On the other hand, due to the effects of overindebtedness on growth and the repayment capacity of low-income countries, the need to alleviate debt and the relevance of such a strategy can be relativized because debt accumulation is Not the cause but the consequence of a low growth [19], in other words debt reduction is not enough to restore investment and growth [20].

On the other hand, due to the effects of overindebtedness on growth and the repayment capacity of low-income countries, the need to alleviate debt and the relevance of such a strategy can be relativized because debt accumulation is Not the cause but the consequence of low growth [19], in other words debt reduction is not sufficient to restore investment and growth [20] [21]. A high debt is therefore a symptom rather than a cause of low growth; the latter being the result of poor macroeconomic management [19].

To believe Easterly [20], this appears in a stronger way in developing countries characterized by a strong preference for the present. Indeed, the governments of these countries are generally seeking to accumulate new debts once reductions have been achieved and in the hope of being eligible for new relief initiatives. The failure of so-called traditional analyses to reduce debt ratios in low-income countries is an illustration of the existence of a moral hazard problem and is indicative of the fact that the relief granted has failed to change the Behaviour of many heavily indebted countries. For example, developing countries are more aware of liquidity problems (debt servicing) than problems of incentives (related to debt).

In line with the work of Easterly [20], our study aims to demonstrate that public overindebtedness negatively impacts economic activity in developing countries. It stands out, however, by giving primacy to the problems of incentives related to the outstanding public debt. The point is to show that a high level of public debt can have a negative impact on economic growth in developing countries.

We then carry out an econometric estimation of a MMG model in the system of a linear relationship between the stock of the public debt and the gross domestic product per capita, based on the data of the Gabonese economy. 
The interest in Gabon follows two justifications. The first is that Gabon is a developing country member of an economic and monetary economy which remains very vulnerable to external shocks (MaruEburekeceku, 2012). All things that expose it to the distrust of public bond markets, thus reducing its budget area in terms of public bond financing. The second is that the Gabonese economy is recording financial events in recent years that significantly affect its economy, which is akin to a crisis in public debt. According to the IMF and the World Bank [22], the Gabonese public debt increased by more than 5 points between 2013 and 2015, which the public authorities in the annex on the debt strategy of the Gabonese state in 2015 also recognise, Accompanying the amending Finance Bill of the year 2015.

The present work will be structured around two axes. The first presents the analytical framework (I) and the second carries out an empirical analysis (II).

\section{The Analytical Framework}

The framework of analysis relies on a state of both theoretical and empirical literature the scissor effect of the public debt.

\subsection{The Theoretical Foundations}

The debates on the impact of the debt burden on investment decisions, and hence on growth, are not recent.

Indeed, since Ricardo and Stuart Mill, the reflection had already looked at the subject, in particular on the notion of the "double burden" of transfers from one economy to another. Known as the "Transfer theory", it stipulates that the payment of debt would create a negative change in the terms of the exchange of the indebted economy, which is a double burden on the economy.

It is necessary to wait for the 80 years for economists to highlight the detrimental role of debt on the anticipation of agents and thus on investment through the theory of the "virtual debt burden" or debt overhang in the strict sense [23]. According to this theory, when an economy can no longer repay its debt, the incentives to invest are changing and take into account the likely impact of the sanctions incurred, which has a declining effect on the investment and, more broadly, on the whole Actions designed to increase income.

This hypothesis will then be the subject of intense debate around the reference article in Eaton and Gersovitz [24]. It remains a burning issue in the economic debates [1]. In particular, the theory of excessive debt, developed by Krugman [16], Sachs [25] [26] and Cohen [27], which establishes that a given threshold of external debt discourages consumption and investment and, therefore, reduces economic growth. These authors differentiate between the "primary" burden of debt, constituted by a high debt service, and the "virtual" burden, which consists of an outstanding debt [28].

The virtual burden can affect through several channels, however, an emphasis is placed on the private investment channel. Indeed, when the debt burden is 
very important, the reduction of resources that emanates from the debt service, can lead to a reduction in investment and hence growth.

One approach to the effects of indebtedness is the impact of the primary burden, in other words, the reduction of resources resulting from the payment of debt servicing. In this regard, debt servicing is the most relevant measure of the debt burden. The debt service would have a foreclosure effect on the investment. The state, forced to reduce its investments in order to ensure the service of the debt, can see two types of effects arise:

1) a direct effect, which consists of a decrease in the level of total investment. The latter can play a decisive role in poor countries where public investment is a significant part of the overall investment;

2) two indirect effects, the first arises from the complementarity between public investment and private investment. Public investment is considered to generate positive externalities for the private sector (by increasing the stock of infrastructure or the stock of human capital, etc.), at least to a certain level [29]. In this perspective, a decrease in the state's expenditure can lead to a decrease in the volume of the investment or a decrease in its productivity. The second indirect effect operates via the exchange rate. A repayment of the external debt creates a puncture on the foreign currency reserves, which helps to depreciate the real exchange rate with the consequence of an improvement of the competitiveness, but also an increase in the cost of capital, the goods Equipment is generally imported into low-income countries.

The theory of the virtual debt burden stipulates that when an economy can no longer repay its debt, the incentives to invest change and take into account the likely impact of the sanctions incurred. This result in a depressing effect on the investment and on all the actions designed to increase income.

In this respect, there are two aspects of the virtual debt burden.

The first aspect comes from the narrow view of the burden. It is based on the outstanding debt, which is the future weight of the debt service. Thus, the expected amount of reimbursement becomes an increasing function of the level of production generated by the debtor country. If the debt is high, potential domestic and foreign investors will anticipate that its repayment is to be financed through increased tax pressure [16]. In other words, the expected return on after-tax capital decreases, which tends to discourage investment and may even lead to capital leakage [30] [31].

The second aspect proceeds from a broader view that any activity involving costs with a view to obtaining higher income in the future may be discouraged, as economic agents anticipate taxation of the fruits of their efforts [15]. An increase in the future debt service may encourage Governments to pursue inflationary policies [30] or to refrain from implementing certain reforms. Furthermore, the uncertainty as to the amount of the debt service that will actually be paid may be a negative signal for investors [32] who would prefer to defer their decision to invest [33]. 
Moreover, the new theories of growth, particularly those of endogenous growth [29] [34] [35], show that debt can have positive effects on growth through investment. Indeed, the sums borrowed, partially or wholly in addition to national savings, can finance the investment (structural expenditure, infrastructure, training and research development) source of growth. Thus, for poor countries, generating too little savings to take advantage of investment opportunities, debt can be a significant source of financing, which justifies the introduction of a non-linear relationship between the debt and growth.

Finally, with the implementation in 1996 of the HIPC Initiative (heavily Indebted Poor countries), the emphasis has been placed on the concept of sustainability of external debt. This initiative aims to assist the poorest countries in the world by making their international debts sustainable. Only then can the countries whose debt is unsustainable qualify for a reduction in their external debt. This approach is based on the view that external debt has a negative effect when it exceeds a certain level [36] [37] [38] [39].

\subsection{The Review of Empirical Literature}

The empirical analysis of the relationship between public debt and growth is based on growth models. It is based on the test of the debt burden hypothesis that postulates the negative impact of public debt on economic growth or on investment. The related works use linear and nonlinear approaches. Our work is particularly focused on the linear approach which has not been neglected in recent times. It is thus evacuating the abundant literature on the nonlinear approach.

Thus, on the linear approach, there are several work that depresses the existence of a depressed effect of the debt service on private investment, education and wage-earning expenses, thus confirming the negative impact of debt On the economy (Greene and Villanueva, 1991); Serious and Yiagadeesen, 2001; (Stephens, 2001). The slowdown in growth is estimated to be due to uncertainty in the payment of the debt service (Oks and Van Wijnbergen, 1995) [32] [40], because the uncertainty about the amount actually paid is a negative signal for investors who prefer to defer their decision to invest.

Other analyses show that the debt service does not directly affect the rate of growth, but rather through the predatory effect of debt servicing on public expenditures [41]. The payment of the external debt service tends to oust public spending leading to a decline in overall investment and its outstanding influence on the incentives of private economic agents by increasing tax pressure [23].

The vast majority of the work mainly relies on the investment or growth of the gross domestic product (GDP), but some of them retain the total investment for reasons of data availability. As for the explanatory variables, the studies take the external debt, in the context of the debt overhang, to the forefront, and the indebtedness of GDP or exports to introduce the crowding-out effect. The explanatory variables taken into account are the investment rate or inflation rate and 
exchange rate to describe the macroeconomic environment in the version of the debt overhang.

Using several alternative variables to measure overindebtedness, in the case of the Philippines using time series for a single country, Borensztein [42] shows that there is a negative relationship between external debt and the investment. But this impact differs depending on the type of overindebted variables used.

Using a panel of 13 heavily indebted countries, DESHPABD [43] highlights, on the one hand, a negative relationship between external debt and investment and shows, on the other hand, that when there is debt overhang, external debt tends to capture the effect Variables that traditionally explain the investment. In this context, the debt overhang would explain the decline in investment in developing countries [44].

It should be noted that some studies using the linear form rather emphasize a positive relationship (Devarajan et al., 1996).

\section{Empirical Analysis}

We would mainly like to make an econometric analysis of the hypothesis of an inverse relationship between public debt and economic growth. For this purpose, we estimate the linear form of the relationship between public debt and economic growth.

We first present the estimation strategy before highlighting the results of the estimation and their interpretation.

\subsection{Estimation Strategy}

Following Mendoza et al. [45], which builds on the growth model of Barro and Sala-i-Martin [46], we estimate a linear relationship between public debt and economic growth with a view to highlighting the negative impact of growth in the debt on investment in Gabon, which results in the scissor effect of the public debt.

Our estimate is unique, however, in that it holds economic growth as the only dependent variable. It is in the explanatory variable public debt that we distinguish the service of the debt and its outstandings, in order better to verify the assumptions of debtoverhang and debtcrowding out in the case of Gabon.

We proceed in turn to the estimation of the following linear equations:

$$
\begin{gathered}
Y_{t}=a_{0}+a_{1} D_{t}+b X_{t}+\mu_{t} \\
Y_{t}=m_{0}+m_{1} S D_{t}+v X_{t}+\mu_{t}
\end{gathered}
$$

where, $Y_{t}$ represents GDP measuring economic growth at time $t ; D_{t}$ is the outstanding debt at time $t, S D_{t}$ represents the debt service at time $t ; X_{t}$ consists of the set of control variables at time $t$.

All variables are expressed in logarithm so that all coefficients $a, b$, metv can be interpreted as elasticities.

$a_{0}$ etm $_{0}$ are the constant terms, representing unexplained economic growth, 
while $u_{t}$ symbolizes the idiosyncratrique error.

We hold two categories of variables, namely the variables of interest, on the one hand, and the control variables, on the other.

With regard to the variables of interest, we have the public debt that we define as the ratio of the outstanding public debt to GDP in the Equation (1) and as the ratio of the public debt service as a percentage of GDP in Equation (2) [22].

These two variables allow us to test our hypothesis of work, namely that public debt has a negative impact on economic growth, which we interpret as a chisel effect. Precisely, we check through the impact of the outstanding public debt the assumption of the debt overhang. That of the public debt service allows taking into account the foreclosure effect of the debt, describing the crowding out of the public debt.

It is therefore expected that $a_{1}$ and $m_{1}$ are negative.

With regard to the control variables, we are leaving both recent work on economic growth [47] [48] and the traditional explanations of economic growth. We first retain the growth rate per head of the previous period in order to measure the remedial effect or conditional convergence.

Indeed, the neoclassical economic model argues that low-income countries that initially have lower technological and financial levels will tend to grow faster than more advanced countries. The conditional convergence hypothesis therefore implies that the coefficient of the growth rate per retarded head is significantly negative.

Secondly, the ratio of investment to GDP, seized by the gross formation of fixed capital as a percentage of GDP, is taken into account because it is a traditional determinant of economic growth. In the neo-classical growth model, in the closed economy, the savings rate is exogenous and equal to the ratio of the investment on production. A higher saving rate increases the long-term equilibrium level of production per worker and thus increases the growth rate for a starting value of GDP. However, an inverse causal relationship (growth to investment) may occur, particularly in the case of open economies. While differences in savings rates are exogenous in relation to growth, the decision to invest in the country rather than abroad reflects the prospects for investment returns, which refers to the internal opportunities opened by the Growth.

Therefore, let us involve the growth rate of the population as growth models positively link it to the growth rate of the economy. In favourable circumstances, industrialization can make population growth a valuable stimulus to increase the standard of living, both by providing a workforce to exploit natural resources and Expanding the markets needed to absorb and profit from mass production.

Lastly, we feed the model by four other explanatory variables, namely the commercial opening seized by exports as a percentage of GDP, the seigniorage captured by the money supply, the inflation measured by the change in the index Prices and the real interest rate. In this we rely on the broad economic literature and mainly on the work on the Determinants of economic Growth [29] [47]-[52]. 
Data from all control variables are extracted from the World Bank's Cdrom World Development Indicators [17].

The interest of introducing all control variables is to make the model more robust. Even if we run the risk of getting the low-significant coefficients.

The estimation of the public debt impact on economic growth does not escape the econometric difficulties more generally encountered by growth regressions [53]. This can lead to several inconsistencies.

First, there may be reverse or simultaneous causality between the explanatory variables and economic growth, which poses a problem of endogeneity that could skew the estimation.

Second, like Ehrhart et al. [47], we introduce a delayed dependent variable (the growth rate per head) in the explanatory variables to look for the possibility of conditional convergence. However, such a presence may produce biased estimated coefficients since, according to Nickell [54], GDP per capita is by construction correlated with the term error.

To address these problems, we use the econometric technique of the Generalized System moments Method (GMM) proposed by Arellano and Bover [55] and Blundell and Bond [56], which has the triple advantage of replacing the moments Theoretical of the population by empirical moments, to correct the bias of endogeneity of the explanatory variables and to evaluate without bias the dynamic processes.

Inscribed in the deepening of the GMM Estimator proposed for the first time by Hansen [57], Blundell and Bond [56], suggest a system MMG estimator using simultaneously the equations in first difference and those in level, which proves to be more efficient than the GMM estimator in the first difference developed by Arellano and Bond [58].

We use the GMM estimator in one step system.

To test the validity of the use of lagged variables, we proceed to Hansen's standard test which is based on the null hypothesis of the absence of correlation between instrumental variables and the residual and the correlation test, which is based on the null hypothesis of the absence of second-order correlation in errors.

\subsection{Results of the Estimate and Their Interpretation}

The results of the estimate are carried over in Table 1.

The tests are consistent with the GMM system estimation in terms of autoregressive processes and instrument validation. Indeed, the Sargan over-identification test and the second-order autocorrelation test (A (2) validate the specification of the GMM estimation in the system, since the parameters of the AR (1) and the AR (2) are significantly different from zero. The critical probability associated with Hansen's J statistic shows that at nearly $96 \%$ for the model with outstanding public debt and $95 \%$ for the model with public debt service, the over-identification hypothesis is valid. 
Table 1. Results of the GMM estimation of the linear relationship public debt and economic growth the dependent variable: Gross domestic product per capita (GDPC).

\begin{tabular}{ccc}
\hline The explanatory variables & $\begin{array}{c}\text { model with outstanding } \\
\text { public debt (D) }\end{array}$ & $\begin{array}{c}\text { model with the Public debt } \\
\text { service (DS) }\end{array}$ \\
\hline $\begin{array}{c}\text { Gross domestic product per capita } \\
\text { lagged (GDPC) }\end{array}$ & $-0.17^{* * *}$ & $-0.23^{* * *}$ \\
Public debt (d) & $-0.04^{* *}$ & $0.02^{* * *}$ \\
Population growth rate (POP) & $-0.35^{* * *}$ & $-0.38^{* * *}$ \\
The degree of trade openness & -0.0078 & -0.02 \\
(EXPORT) & $0.09^{* * *}$ & $0.085^{* * *}$ \\
Investment rate (INVEST) & $-0.13^{* *}$ & $-0.13^{* * *}$ \\
The Seigniorage (MM) & $0.002^{* * *}$ & $0.002^{* * *}$ \\
Inflation (INFL) & $0.00015^{* * *}$ & $0.001^{* * *}$ \\
The real interest rate (TIR) & $1.2^{* * *}$ & $1.19^{* * *}$ \\
AR (1) & $-0.59^{* * *}$ & $-0.69^{* * *}$ \\
AR (2) & 00.84 & 0.87 \\
R & 2.02 & 1.89 \\
Durbin Watson & 6.82 & 7.22 \\
J-statistic (Sargan test) & 0.96 & 0.95 \\
Prob (J-statistic) & 26 & 26 \\
Number of Instruments & & \\
\hline
\end{tabular}

Source: Calculation made by the author using Eviews 7. NB: $\left({ }^{* * *}\right)$ significant coefficients at the threshold of $1 \%$, ${ }^{* *}$ ) significant coefficients at the threshold of $5 \%$ and $\left(^{*}\right)$ coefficients significant at the $10 \%$ threshold.

All factors are significant. If the assumption of a virtual debt burden is confirmed in Gabon, the primary burden is reversed. In the virtual sense, public debt is a burden on the Gabonese economy.

Indeed, the results show that the relationship between the outstanding public debt and the rate of economic growth is negative in Gabon over the period 1980 to 2015 . An increase in the public debt of $1 \%$ leads to a decrease in the relatively low per capita economic growth rate of $0.04 \%$. In other words, Gabon is unable to adequately repay its debt. Its outstanding debt is so important that incentives to invest are changing by taking the mistrust of lenders and the impact of high default risk, thus depressing economic growth.

In the primary sense, the public debt does not seem to demotivate economic activity. Rather, the increase in the debt service is accompanied by an increase, certainly low, in the growth rate of the economy by $0.02 \%$. In these circumstances, it may be thought that the payment of the debt service does not reduce resources to the point of thwarting economic activity. The debt service would therefore not have a predatory effect on investments in particular public. In other words, the state is not forced to reduce its investment to ensure its debt service.

Better to believe the results, the payment of debt service would play for the 
Gabonese economy a kind of guarantee of economic growth. This situation does not seem plausible if we refer to Gabon's sluggish economic growth while its public debt increases (Table 2).

The assessment of debt sustainability based on the institutional strength and quality of policies in Gabon effectively shows that this country is positioned in the category of the worst performers. Of the five debt indicators, three are assessed below the thresholds for low economic performance. That is to say that Gabon does not seem able to maintain a higher debt burden, which puts it in the face of a high risk of high debt.

A more specific analysis shows first that the updated ratio of public debt to budgetary revenues that determines the share of public debt in state financing is lower than the average threshold of $250 \%$ recommended by the IMF. However, a state is considered to be overindebted when the public debt represents an important part of the public revenue. This is the case of Gabon, which records a ratio of $233.15 \%$. Secondly, with a debt-servicing ratio of $16.22 \%$ in budgetary revenue, Gabon is at a high risk of overindebtedness. The same level of risk is assessed by the ANV debt ratios (91.42\%) and debt service (6.36\%) compared to exports. Finally, only the ANV ratio of debt to GDP, culminating in $52.54 \%$ and corresponding to sufficient performance of economic policies, suggests that Gabon is able to withstand its debt. The risk of overindebtedness is very low.

Overall, the analysis of the debt sustainability framework suggests that $\mathrm{Ga}$ bon's public debt is excessive.

There are so many things that are necessary to believe that debt servicing is not the most relevant measure of the debt burden for this economy, which is easily understood with regard to the opacity in the management of the Gabonese public debt that leads to Unreliable data.

Added to this is the fact that debt-related data are often confusing because of the diversity of definitions, the covered area and the Methods of Evaluation (Fournier and Fall, 2015); (Bloch and Fall, 2015).

This means that the Gabonese public debt has scissor effect on economic activity.

\section{Conclusions}

The point was to show that the public debt captured by the stock of public debt

Table 2. Debt indicators for Gabon in 2015 from the DSA.

\begin{tabular}{cccc}
\hline \multirow{2}{*}{ Indicators } & \multicolumn{3}{c}{ Evaluation of the institutional strength and quality of the policies } \\
\cline { 2 - 3 } & Insufficient & average & satisfactory \\
\hline ANV debt/GDP & & & $52.54 \%$ \\
ANV debt/exports & $91.42 \%$ & \\
Debt Service/export & $6.36 \%$ & $233.15 \%$ \\
ANV Debt/budget revenue & & \\
Debt Service/budget revenue & $16.22 \%$ & \\
\hline
\end{tabular}

*DSA: Debt Sustainability Analysis. ANV: Actuel Net Value. Source: Calculations made by the author. 
had a negative impact on economic growth in developing countries. Based on the Gabonese economy, we have estimated a model GMM system of a linear relationship between the stock of public debt and the gross domestic product per capita over the period from 1980 to 2015. It appears that an increase in the public debt causes a deceleration of economic activity, reflecting a situation of over-indebtedness whose consequence is the disincentive to investment due to the existence of a risk of high default of the debt.

Public debt is thus a burden in the virtual sense for the Gabonese economy, which must be reduced in order to restore efficiency in the financing of the economy through public bonds.

\section{Conflicts of Interest}

The authors declare no conflicts of interest regarding the publication of this paper.

\section{References}

[1] Reinhart, C.M. and Rogoff, K.S. (2009) This Time Is Different: Eight Centuries of Financial Folly. Princeton: Princeton University Press.

[2] Woodford, M. (1990) Public Debt as Private Liquidity. The American Economic Review, 80, 382-388.

[3] Aiyagari, S. and Mc Grattan, E. (1998) The Optimum Quantity of Debt. Journal of Monetary Economics, 42, 447-469. https://doi.org/10.1016/S0304-3932(98)00031-2

[4] Desbonnet, A. and Kankanamge, S. (2008) Fluctuations macroéconomiques et dette publique. Revue Economique, 59, 583-593. https://doi.org/10.3917/reco.593.0583

[5] Barro, R. (1979) On the Determination of the Public Debt. Journal of Political Economy, 87, 940-971. https://doi.org/10.1086/260807

[6] Bernheim, B.D. (1989) A Neoclassical Perspective on Budget Deficits. Journal of Economic Perspectives, 3, 55-72. https://doi.org/10.1257/jep.3.2.55

[7] Diamond, P. (1965) National Debt in a Neo-Classical Growth Model. American Economic Review, 55, 1126-1150.

[8] Olson, M. (1965) The Logic of Collective Action. Havard University Press, Cambridge.

[9] Elmendorf, D. and Mankiw, G. (1999) Government Debt. In: Taylor, J. and Woodford, M., Ed., Handbook of Macroeconomics, Volume 1c, Elsevier, North Holland, 1615-1669.

[10] De Grauwe, P. (2011) The Governance of a Fragile Eurozone. Working Document, 346 CEPS

[11] Cochrane, J. (2001) Long-Term Debt and Optimal Policy in the Fiscal Theory of the Price Level. Econometrica, 69, 69-116. https://doi.org/10.1111/1468-0262.00179

[12] Nautet, M. and Van Meensel, L. (2011) Economic Impact of the Public Debt. Economic Review, 3.

[13] Deppler, M. and Williamson, M. (1987) Capital Flight: Concepts, Measurement, and Issues, Staff Studies for the World Economic Outlook. International Monetary Fund, Washington DC, 39-58.

[14] Ajayi, S.I. (1997) An Analysis of External Debt and Capital Flight in the Severely 
Indebted Low Income Countries in Sub-Saharan Africa. International Monetary Fund Research Department, Washington DC.

[15] Corden, W.M. (1988) Debt Relief and Adjustment Incentives. IMF Staff Papers, 35, 628-643. https://doi.org/10.2307/3867113

[16] Krugman, P. (1988) Financing vs. Forgiving a Debt Overhang. NBER Working Paper No. 6.

[17] Krugman, P. (1988) Market-Based Debt-Reduction Schemes. NBER Working Paper No. 2587.

[18] Elbadawi, I. and Ndulu, B. (1996) Long-Term Development and Sustainable Growth in Sub-Saharan Africa.

[19] Bulow, J. and Rogoff, K. (1990) Cleaning Up Third World Debt without Getting Taken to the Cleaners. Journal of Economic Perspectives, 4, 31-42. https://doi.org/10.1257/jep.4.1.31

[20] Easterly, W. (2002) What Did Structural Adjustment Adjust? The Association of Policies and Growth with Repeated IMF and World Bank Adjustment Loans. Working Papers 11, Center for Global Development.

[21] Asiedu, E. (2003) Foreign Direct Investment in Africa: The Role of Government Policy, Institutions and Political Instability. Working Paper, University of Kansas, Lawrence, KS.

[22] Banquemondiale (2015) World Development Indicators. Cdrom.

[23] Idlemouden and Raffinot (2005) Le fardeau virtuel de la dette extérieure. Eurisco Cahier No. 2005-03.

[24] Eaton, J. and Gersovitz, M. (1981) Debt with Potential Repudiation: Theoretical and Empirical Analysis. Review of Economic Studies, 48, 289-309. https://doi.org/10.2307/2296886

[25] Sachs, J. (1989) Conditionality, Debt Relief, and the Developing Country Debt Crisis. In: Sachs, J.D., Ed., Developing Country Debt and Economic Performance, Vol. 1: The International Financial System, University of Chicago Press, Chicago, 255-295.

[26] Sachs, J. (1989) Developing Country Debt and the World Economy. University of Chicago Press, Chicago. https://doi.org/10.7208/chicago/9780226733234.001.0001

[27] Cohen, D. (1993) Low Investment and Large LDC Debt in the 1980's. American Economic Review, 83, 436-449.

[28] Gurbuz, B. and Raffinot, M. (2001) Dette publique et investissements privés. Le cas de la Turquie. Economie Internationale No. 86, CEPII.

[29] Barro, R. (1990) Government Spending in a Simple Model of Economic Growth. Journal of Political Economy, 98, 103-125. https://doi.org/10.1086/261726

[30] Agénor, P.-R. and Montiel, P.J. (1996) Development Macroeconomics. Princeton University Press, Princeton, NJ.

[31] Calvo, G.A. (1998) Growth, Debt and Economic Transformation: The Capital Flight Problem. In: Coricelli, F., di Matteo, M. and Hahn, F., Eds., New Theories in Growth and Development, New York.

[32] Dijkstra, G. and Hermes, N. (2001) The Uncertainty of Debt Service Payments and Economic Growth of Highly Indebted Poor Countries: Is There a Case for Debt Relief? UNU/WIDER Development Conference on Debt Relief, Helsinki, Finlande, 17-18 August 2001.

[33] Serven, L. (1997) Uncertainty, Instability and Irreversible Investment: Theory, Evi- 
dence and Lessons from Africa. World Bank Policy Research Working Paper No. 1722 .

[34] Lucas, R.E. (1988) On the Mechanics of Economic Development. Journal of Monetary Economics, 22, 3-42. https://doi.org/10.1016/0304-3932(88)90168-7

[35] Romer, P. (1986) Increasing Returns and Long Run Growth. Journal of Political Economy, 98, S71-S102. https://doi.org/10.1086/261725

[36] Reinhart, C.M. and Rogoff, K.S. (2010) Growth in a Time of Debt. American Economic Review, 100, 573-578. https://doi.org/10.1257/aer.100.2.573

[37] Reinhart, C. and Rogoff, K. (2010) From Financial Crash to Debt Crisis. NBER, Working Paper 15795.

[38] Kumar, M.S. and Woo, J. (2010) Public Debt and Growth. IMF Working Paper No. 10/174, Fondsmonétaire International.

[39] Rother, C.-W. (2012) The Impact of High Government Debt on Economic Growth and Its Channels: An Empirical Investigation for the Euro Area. European Economic Review, 56, 1392-1405. https://doi.org/10.1016/j.euroecorev.2012.06.007

[40] Cohen, D. (1995) Large External Debt and (Slow) Domestic Growth. Journal of Economic Dynamics and Control, 19, 1141-1163. https://doi.org/10.1016/0165-1889(94)00822-Y

[41] Clemens, B.J., Rina, B. and Toan Quoc, N. (2003) External Debt, Public Investment and Growth in Low-Incomes Countries. IMF Working Paper WP/03/249.

[42] Borensztein, E. and Overhang, D. (1990) Debt Reduction and Investment: The Case of the Philippines. IMF Working Paper, 1-27.

[43] Deshpande, A. (1997) The Debt Overhang and Disincentive to Invest. Journal of Development Economics, 52, 169-187. https://doi.org/10.1016/S0304-3878(96)00435-X

[44] Savvides, A. (1992) Investment Slowdown in Developing Countries during the 1980s: Debt Overhang or Foreign Capital Inflows? Kyklos, 45, 363-378. https://doi.org/10.1111/j.1467-6435.1992.tb02121.x

[45] Mendoza, R., et al. (2003) Deuda externa, inversión y crecimiento en Colombia, 1970-2002. Borradores de Economía No. 272, Banco de la República de Colombia.

[46] Barro, R.J. and Sala-i-Martin, X. (1995) Economic Growth. McGraw-Hill, New York.

[47] Ehrhart, H., Minea, A. and Villieu, P. (2009) Deficit, Seigniorage and the Growth Laffer Curve in Developing Countries. Document de travail de la série, Etudes et Documents No. 26, CERDI.

[48] Minea and Villieu (2009; 2010) Dette publique, croissance et bien être: Une perspective de long terme. DT CERDI.

[49] Vedder, R.K. and Gallaway, L.E. (1998) Government Size and Economic Growth. Joint Economic Committee.

[50] Pevcin, P. (2004) Economic Output and the Optimal Size of Government. Economic and Business Review, 6, 213-227.

[51] Herath, S. (2010) The Size of the Government and Economic Growth: An Empirical Study of Sri Lanka. Discussion Papers WU Vienna University of Economics and Business, Vienna.

[52] Forte, F. and Magazzino, C. (2010) Optimal Size of Government and Economic Growth in EU-27. CREI Working Paper No. 4.

[53] Caselli, F., Esquivel, G. and Lefort, F. (1996) Reopening the Convergence Debate: A 
New Look at Cross-Country Growth Empirics. Journal of Economic Growth, 1, 363-389. https://doi.org/10.1007/BF00141044

[54] Nickell, S. (1981) Biases in Dynamic Models with Fixed Effects. Econometrica, 49, 1417-1426. https://doi.org/10.2307/1911408

[55] Arellano, M. and Bover, O. (1995) Another Look at the Instrumental Variable Estimation of Error-Components Models. Journal of Econometrics, 68, 29-51. https://doi.org/10.1016/0304-4076(94)01642-D

[56] Blundell, R. and Bond, S. (1998) Initial Conditions and Moment Restrictions in Dynamic Panel Data Models. Journal of Econometrics, 87, 115-143. https://doi.org/10.1016/S0304-4076(98)00009-8

[57] Hansen, L.P. (1982) Large Sample Properties of Generalized Method of Moments Estimators. Econometrica, 50, 1029-1054. https://doi.org/10.2307/1912775

[58] Arellano, M. and Bond, S. (1991) Some Tests of Specification for Panel Data: Monte Carlo Evidence and an Application to Employment Equations. Review of Economic Studies, 58, 277-297. https://doi.org/10.2307/2297968 